\title{
Indigenous Peoples, Urbanization Processes, and Interactions with Extraction Firms in Russia's Arctic
}

\author{
MARLENE LARUELLE
}

$\mathrm{R}^{u}$ ussia is unique on the circumpolar landscape in that indigenous communities constitute only a small percentage of its Arctic population. Whereas they represent 80 percent of Greenland's population, 50 percent of Canada's, 20 percent of Alaska's, and 15 percent of Norway's Arctic regions, they make up less than 5 percent of the population of Arctic Russia. Although indigenous peoples have a more solid demography than Russians and have therefore seen their share of the Arctic population slowly increase over the past two decades, their rights remain fragile. Moscow does not consider the Arctic to have a specific status due to the presence of indigenous peoples, and its reading of the region is still very much shaped by the imperial past, the memory of an easy conquest (osvoenie) of territories deemed "unpopulated," and the exploitation of the region's subsoil resources.

The Soviet mechanism of creating nations and the status accorded to them by the Russian federal system continue to protect some indigenous rights but on a limited basis. Groups on the list of small-numbered indigenous peoples (korennye malochislennye narody) enjoy the recognition of such rights as self-organization as a community, protection of their language, and the right to use nature in their traditional way. ${ }^{1}$ To be included on this list, these groups must live on their historical territory, preserve their language and traditional way of life, define themselves as separate ethnicities, and not exceed 50,000 persons. $^{2}$ Of the forty-five groups currently recognized, twenty-one live in the Arctic zone, with the remainder spread across the regions of Sakhalin, Khabarovsk, Vladivostok, Southern Siberia, and the North Caucasus.

The definition of small-numbered indigenous peoples gives rise to three major problems. First, the Komi, Karelian, and Sakha populations are all far larger in number and are not included in this categorization. They belong to the larger set of indigenous peoples (korennye narody) 
and have rights attached only to the existence of a national republic or district where they are the titular group. As the largest group, with almost half a million members, Sakha, in particular, have been protesting against the lack of recognition of their indigeneity and the fact that Russian historiography considers them colonizers because they originally came from southern Siberia and are Turkic-speakers, and thus related to the Altay-Mongolian world. They have sometimes found themselves in conflict with the small-numbered indigenous peoples, such as Evenks, Evens, Dolgans, and Chukchi, who comprise 4.3 percent of the republic's population. In 2016, the Constitutional Court of the Sakha Republic (Yakutia) concluded years of struggle by recognizing the Sakha as an indigenous people, but this republic-level decision does not impact the federal policy of excluding larger groups. ${ }^{3}$

Second, to be considered to belong to a small-numbered indigenous people, individuals have to live on their historical territory and preserve their language and traditional way of life. As a result, those who move to cities-a growing number-are stripped of their rights, which remain attached to their original home. This hampers their chances to reinvent and protect indigenous identity in an urban context.

Third, the rights accorded to this status are far too limited to be an efficient protection. Russia has not ratified the 1969 ILO Convention on Indigenous and Tribal Rights, which is binding on only seventeen countries, mainly in Latin America. It is opposed to the clause on property rights, which would necessitate long negotiations about the territories occupied by the massive industrial combines and would undermine the assets of the Russian state or its administrative subjects. ${ }^{4}$ Contrary to what its federal structure might lead some to believe, and in contrast to Canada, Denmark, and Norway, Russia does not grant its indigenous peoples any political autonomy, nor does it consult them about subsoil exploitation. ${ }^{5}$ Only in 2009 did Moscow validate a law to register territories of traditional nature use of regional and local significance, ${ }^{6}$ allowing for modest compensation for damage to these lands by subsoil users. $^{7}$

Numerous challenges exist to preserving indigenous cultures. One of the key ones relates to rapid urbanization. Since the 1960s, most of the population growth in the whole circumpolar Arctic has occurred in urban centers, due both to in-migration and to natural increase via high birth rates. ${ }^{8}$ This urbanization has been uneven: small settlements are tending toward depopulation, while large urban centers such as Anchorage, Whitehorse, Nuuk, Reykjavik, Akureyri, Tromsø, Bodo, and Luleå have been growing rapidly. ${ }^{9}$ Today, only the Northwest Territories 
and Nunavut in Canada, as well as the Faroe Islands, based on a more dispersed economy, are still majority rural; the rest of the Arctic regions have between two-thirds and three-quarters of their populations residing in urban areas. Average urbanization is highest in Russia: in most of its sixteen regions, between 66 and 92 percent of the population is classified as urban, with the Murmansk region the most urbanized at 93 percent. ${ }^{10}$ This circumpolar urbanization is linked to the growth in industrial activities (mostly large-scale fishing, forestry, and mineral extraction), but also to the development of social services, public administration, higher education institutions, military bases, and tourism.

Until the 1960s, cities in the Arctic were created through state intervention, planned by the political center, and erected by a workforce brought in from outside. Their "otherness" to indigenous culture was one of these cities' structural features. This equation has slowly been rewritten with the rising urbanization of indigenous peoples themselves. The Soviet Union was the first to begin urbanizing indigenous communities, followed by North America and Scandinavia in the 1950s and 1960s, and the phenomenon spread in the 1990s and 2000s. Today, Greenland leads on indigenous urbanization: Greenlandic Inuit are 85 percent urbanized, followed by Alaskan natives at 60 percent, Canadian Inuit at 50 percent, and Sámi in the three Scandinavian countries at about 36 percent. In Russia, some indigenous groups, such as the Nenets, remain heavily rural, while others-such as the Mansy, Komi, and Sámi-are more urbanized. But even Nenets are progressively joining the trend toward urbanization: the Nenets population has doubled in the past 80 years, but only 1,000 more people are living in the tundra, where Nenets have traditionally engaged in reindeer-related activities, than were resident there at the 1939 census. Precise figures may vary dramatically depending on the region, but the general trend is that of a rapid urbanization of indigenous peoples: in the Magadan oblast, for example, urban dwellers grew from 33 percent of the indigenous population in 1979 to 69 percent in 2010. Among Russia's Arctic cities, Dudinka dominates with a population that is 77 percent indigenous, followed by Yakutsk at 52 percent. A second group of cities, such as Khanty-Mansiisk and Salekhard, is about 20 percent indigenous.

Urbanization dramatically transforms indigenous identity, disconnecting it from the traditional subsistence economy. This is usually accompanied by a loss of the native language and traditional ecological knowledge and deep transformations of kinship identity. Until recently, studies of indigenous peoples in urban conditions focused primarily on all the social illnesses linked to their failure to integrate into the urban 
fabric — such as social marginalization, unemployment, suicide and alcoholism rates-and physical and symbolic dispossession rather than on the creation of new meanings. Since the second half of the 2000s, a more diversified perspective has emerged, allowing us to identify how indigeneity can be mobilized in urban politics and confirming an indigenous agency that cuts against perceptions of indigenous peoples as being exclusively victims. ${ }^{11}$ This approach is part of a broader global trend toward looking at "indigenous in the city," a dynamic that is particularly visible in Latin America and Australia-New Zealand. ${ }^{12}$

In Russia, having the choice to either stay in the traditional village or leave for the city is now often interpreted as positive. Nenets living in Yamalo-Nenets cities such as Salekhard consider, for instance, that every young person can choose freely between an urban and a rural way of life, which are valued equally. This creates the possibility for families to benefit from both worlds: urbanites can return to the tundra for the summer, while villagers can come to town on administrative, educational or health-related business and get support from relatives already established in town. ${ }^{13}$ Rural migrants to the cities push for their children's integration as a way to provide them with better education and upward social mobility. ${ }^{14}$ One of the most successful ways of appropriating the city and its identity seems to be the creation of new, "globalized" ways of displaying indigenous identity that are attractive enough for the municipal authorities to embrace them too. ${ }^{15}$ In several Arctic cities, young indigenous cultural entrepreneurs have been working with the authorities to create a city "brand" that builds on its indigenous heritage.

Three articles in this issue of Sibirica addresses these matters. Svetlana Sukneva and Marlene Laruelle write about the urbanization of rural Yakuts moving en masse to Yakutsk, while Marya Rozanova's article is devoted to Nenets moving to the small city of Naryan-Mar. The two articles describe similar trends, such as a rural exodus mostly driven by young people and women, who seek professional and educational opportunities unavailable in their villages of origin. A third article, by Vera Kuklina, Sargylana Ignatieva, and Uliana Vinokurova, delves into the birth of a new indigenous "creative class" of students and graduates that is helping Yakutsk brand itself as the genuine indigenous capital of Russia's North.

Another aspect of indigenous urbanization is that urbanization does not limit itself to a physical move to cities. The "urban logic" now extends beyond the city's borders, in that "urban" practices have arrived in indigenous villages. Tourism, food traditions, and niche 
products have contributed to commodifying the rural and shifting local communities from production to consumption. Cell phones allow for long distance communication with those who have left the home community, meaning that social relationships are no longer confined to the community. Improved transport infrastructure means that remote areas are suddenly accessible, altering the subsistence economy of those locales. Fuel-intensive snowmobiles are now seen as crucial to surviving in rural conditions, and jobs performing administrative functions for the local extractive industries or unemployment benefit offices are appearing in isolated villages. ${ }^{16}$ In many respects, even indigenous villages now live in a "globalized" world shaped by urban features.

The central driver of this interaction is the growing presence of energy and mineral extraction companies in tundra regions. Many of those indigenous populations who remain in their settlements of origin have to contend with the arrival of extraction industries, which disturb pastures and impede traditional use of land, flora, and fauna. Tensions between indigenous communities and subsoil users have been rather acute in the Khanty-Mansi-Yugra Autonomous Okrug and the adjacent Yamalo-Nenets Autonomous Okrug, where Nenets must herd their reindeer in such a way as to avoid gas wells and pipelines. ${ }^{17}$ The protests organized by their associations have made the Nenets one of the most widely media-covered indigenous populations in all of Russia.

Given Moscow's participation in the Arctic Council and international pressures regarding indigenous rights, the Kremlin has had to soften its position and encourage Gazprom, Rosneft, and other subsoil users to develop contacts with indigenous representatives. In Yugra, any new license to explore and exploit the subsoil should now be preceded by an agreement between the subsoil user and the owner of the territory of traditional nature use. This agreement may include a compensation mechanism for restricting traditional activities, as well as a promise to coordinate geological exploration with natives, implement certain environmental measures, build transport infrastructure, fund medical and educational services, build housing for the indigenous population, and employ a certain share of the indigenous population.

Nevertheless, the subsidies from intense subsoil exploitation continue to be essentially soaked up by the central government rather than actually benefitting indigenous communities, and the power differential between the latter and the big energy firms often results in uneven agreements. Moreover, as Dominique de Samson Normand de Chambourg discusses in his article, cultural clashes between neftianiki (the "oil men") and Forest Nenets and Khanty continue to happen to the 
detriment of the latter, for whom the violation of the Earth's integrity contradicts a philosophical worldview in which the individual is part of a continuum with nature.

In Sakha, tensions have been less visible but remain perceptible, especially between Alrosa, Russia's state diamond extraction firm and other, mostly private firms extracting gold, gas, oil, precious metals, coal, and timber resources, on the one hand, and indigenous communities, often of "small-numbered indigenous peoples," but also of Yakuts living in the "North Yakutsk core zone" — which the Sakha government hopes to transform into a major extraction and transportation hub for the whole Far East-on the other. In 2010, the Sakha government passed the unique Law "On Ethnological Examination in Traditional Residences and Traditional Economic Activities of Indigenous Peoples of the North of the Republic of Sakha (Yakutia),"18 which compels subsoil users to follow the recommendations given by an Ethnological Expertise Committee and come to an agreement with indigenous communities. The Sakha law, discussed in this issue by Violetta Gassiy, constitutes a better mechanism for defending indigenous rights than the Yugra-style agreement, as compensation is decided by an independent expert committee commissioned by the authorities rather than by an agreement between powerful subsoil users and weaker indigenous communities.

Despite some improvements and increased awareness of environmental and indigenous issues on the part of the Russian authorities and big firms, the prospect of indigenous communities gaining full control over their fates remains a distant one. Those who continue to live in their traditional villages find themselves even more devoid of "fate control" than their counterparts living in cities, who can at least attempt to re-invent a new indigenous identity under urban conditions.

\footnotetext{
Marlene Laruelle, $\mathrm{PhD}$, is director and research professor at the Institute for European, Russian and Eurasian Studies, Elliott School of International Affairs, The George Washington University. Dr. Laruelle is also a codirector of PONARS (Program on New Approaches to Research and Security in Eurasia) and Director of GW's Central Asia Program. She has authored Russia's Strategies in the Arctic and the Future of the Far North (2013), and edited New Mobilities and Social Changes in Russia's Arctic Regions (2016). ORCID: 0000-0001-8289-2695. Email: laruelle@gwu.edu.
} 


\section{Notes}

1. Indra Ǿverland and Helge Blakkisrud, "The evolution of federal indigenous policy in the post-Soviet North," in Tackling space: Federal politics and the Russian North, ed. Helge Blakkisrud and Geir Hønneland (Lanham, MD: University Press of America, 2006), 175-176.

2. “Postanovlenie Pravitel'stva Rossiiskoi Federatsii 24 marta 2000 No 255 `O edinom perechne korennykh malochislennykh narodov Rossiiskoi Federatsii'” [Decree No. 255 of the Government of the Russian Federation of March 24, 2000 "On a unified enumeration of small-numbered indigenous peoples of the Russian Federation"], http://demoscope.ru/weekly/knigi/zakon/zakon047.html.

3. "Postanovlenie Konstitutsionnogo Suda Respubliki Sakha (Iakutiia) ot 21 oktiabria 2016 g. №4-P ‘Po delu o tolkovanii polozheniia stat’i 42 Konstitutsii (Osnovnogo Zakona) Respubliki Sakha (Iakutiia)'” [Resolution of the Constitutional Court of the Sakha Republic (Yakutia) of October 21, 2016, No. 4-P "In the case of the interpretation of the provisions of Article 42 of the Constitution (Basic Law) of the Republic of Sakha (Yakutia)"], http://base.garant.ru/48155860/.

4. Indra Ǿverland, "Indigenous rights in the Russian Far North," in Russia and the North, ed. Elana Wilson Rowe (Ottawa: University of Ottawa Press, 2009), 165-186.

5. Alexandra Tomaselli and Anna Koch, "Implementation of indigenous rights in Russia: Shortcomings and recent developments," International Indigenous Policy Journal 5, no. 4 (2014), doi: 10.18584/iipj.2014.5.4.3.

6. Government of the Russian Federation, "Rasporiazhenie Pravitel'stva RF ot 8 maia 2009 g. No. 631-r 'Ob utverzhdenii perechniia mest traditsionnogo prozhivaniia i traditsionnoi khoziaistvennoi deiatel'nosti korennykh malochislennykh narodov RF i perechniia vidov ikh traditsionnoi khoziaistvennoi deiatel'nosti'" [Decree of the Government of the Russian Federation of May 8, 2009 No. 631-r "On approval of the list of places of traditional residence and traditional economic activities of the indigenous small peoples of the Russian Federation and a list of types of their traditional economic activities"], May 8, 2009, http://www.garant.ru/products/ipo/prime/doc/95535/.

7. Ministry of Regional Development of the Russian Federation, "Prikaz Minregiona $\mathrm{RF}$ ot 09.12. $2009 \mathrm{~N} 565$ `Ob utverzhdenii metodiki ischisleniia razmera ubytkov, prichinennykh ob"edineniiam korennykh malochislennykh narodov Severa, Sibiri i Dal'nego Vostoka Rossiiskoi Federatsii v rezul'tate khoziaistvennoi i inoi deiatel'nosti organizatsii vsekh form sobstvennosti i fizicheskikh lits v mestakh traditsionnogo prozhivaniia i traditsionnoi khoziaistvennoi deiatel'nosti korennykh malochislennykh narodov" [Order of the Ministry of Regional Development of the Russian Federation of 09.12.2009 N 565 “On the approval of the methodology for calculating the amount of losses caused to associations of indigenous peoples of the North, Siberia and the Far East of the Russian Federation as a result of economic and other activities of organizations of all forms of ownership and individuals in places of traditional residence and traditional 
economic activity of the indigenous peoples of the Russian Federation"], December 9, 2009, http://www.consultant.ru/document/cons_doc_LAW_96747/.

8. Rasmus Ole Rasmussen, ed., Megatrends (Copenhagen: Nordic Council of Ministers, 2011), 22. See also Northern Forum, "Cities on ice: Population change in the Arctic," https://www.northernforum.org/en/news/481-cities-onice-population-change-in-the-arctic (accessed December 21, 2018).

9. Ryan Weber et al., "Urbanization and land use management in the Arctic: An investigative overview," in Northern sustainabilities: Understanding and addressing change in the circumpolar world, ed. Gail Fondahl and Gary N. Wilson (New York: Springer, 2017), 269-284.

10. Joan Nymand Larsen and Gail Fondahl, eds., Arctic human development report: Regional processes and global linkages (Copenhagen: Nordic Council of Ministers, 2014), 94.

11. For a good summary of this new trend of publications, see Peter Schweitzer, "Korennye narody i urbanizatsiia na Aliaske i na Kanadskom Severe" [Indigenous peoples and urbanization in Alaska and the Canadian North], Etnograficheskoe obozrenie 1 (2016): 10-22.

12. Evelyn Peters and Chris Andersen, eds., Indigenous in the city: Contemporary identities and cultural innovation (Vancouver: UBC Press, 2014).

13. Yelena Vladimirovna Lyarskaya, "Severnye internaty i transformatsiia traditsionnoi kul'tury: na primere nentsev Yamala" [Northern boarding schools and the transformation of traditional culture: The example of the Nenets of Yamal] (PhD diss., European University at St. Petersburg, 2003).

14. A.G. Tomaska, "Migranty Respubliki Sakha (Yakutiia): voprosy integratsii detei sel'skikh migrantov" [Migrants of the Republic of Sakha (Yakutia): Issues of integration of children of rural migrants], Severo-Vostochnyi gumanitarnyi vestnik 1, no. 18 (2017): 58-64.

15. Jenanne Ferguson and Lena Sidorova, "What language advertises: Ethnographic branding in the linguistic landscape of Yakutsk," Language Policy 17, no. 1 (2018): 23-54.

16. Vera Kuklina and Edward C. Holland, "The roads of the Sayan Mountains: Theorizing remoteness in Eastern Siberia," Geoforum 88 (2018): 36-44.

17. T.N. Vasil'kova, A.V. Evai, E.P. Martynova, and N.I. Novikova, Korennye malochislennye narody i promyshlennoe razvitie Arktiki [Indigenous smallnumbered peoples and the industrial development of the Arctic] (Moscow: Shchadrinskii dom pechati, 2011); E.P. Martynova and N.I. Novikova, Tazovskie nentsy $v$ usloviiakh neftegazovogo osvoeniia [The Taz Nenets under conditions of oil and gas development] (Moscow: RAN, 2012).

18. Law of the Republic of Sakha (Iakutiia) 820-Z No. 537-IV adopted on 14.04.2010 (Edited on 18.12.2015) "On ethnological expertise in places of traditional residence and traditional economic activities of indigenous small peoples of the North of the Republic of Sakha (Iakutiia)," Yakutsk Statements 30 (2010); Government of the Russian Federation, "Rasporiazhenie Pravitel'stva RF ot 8 maia 2009 g. No. 631-r." 